\title{
Use of local muscle flaps to cover leg bone exposures
}

\section{Uso de retalhos musculares locais para cobertura de exposições ósseas na perna}

Francisco d'Avila ${ }^{1}$; Diogo Franco, TCBC -RJ²; Bianca d'Avila ${ }^{3}$; Marcio Arnaut Jr., TCBC -RJ4

A B S T R A C T

\begin{abstract}
Objective: To evaluate the use of the medial gastrocnemius muscle and/or soleus muscle flaps as surgical treatment of the leg bone exposure. Methods: We retrospectively analyzed the medical records of patients undergoing transposition of the medial gastrocnemius and / or soleus for treating exposed bone in the leg, from January 1976 to July 2009, gathering information on epidemiological data, the etiology the lesion, the time between the initial injury and muscle transposition, the muscle used to cover the lesion, the healing evolution of the skin coverage and the function of the gastrocnemius-soleus unit. Results: 53 patients were operated, the ages varying between nine and 84 years (mean age 41); 42 were male and 11 female. The main initial injury was trauma $(84.8 \%)$, consisting of tibia and / or fibula fracture. The most frequently used muscle was the soleus, in 40 cases (75.5\%). The rank of 49 patients (92.5\%) was excellent or good outcome, of three (5.6\%) as regular and of one $(1.9 \%)$ as unsatisfactory. Conclusion: the treatment of bone exposure with local muscle flaps (gastrocnemius and/or soleus) enables obtaining satisfactory results in covering of exposed structures, favoring local vascularization and improving the initial injury. It offers the advantage of providing a treatment in only one surgical procedure, an earlier recovery and reduced hospital stay.
\end{abstract}

Key words:Lower extremity; muscle - skeletal; myocutaneous flap; leg - surgery.

\section{INTRODUCTION}

T he anterior face of the tibia is covered by the common integument, which features a rather scarce and inelastic subcutaneous tissue. Injuries and infections in this region often become ulcerative lesions, with consequent bone exposure, and may lead to tissue necrosis.

Among the traumatic injuries, open tibial fractures are the main cause of ulcerative lesions, despite adequate surgical treatment in the emergency room. Direct trauma and manipulation of surgical access determine great soft tissue suffering, often evolving to bone exposure.

Chronic osteomyelitis of the tibia continues to pose concern because of its frequency and the difficulty of treatment, since we can find fistulas, scars and adhesions to the bone plane. The access to the sequestrectomies may result in suture dehiscence and necrosis, which compromises the therapeutic success. For these reasons, reconstructive surgery is an essential part of such treatment.

Given the aforementioned, in addition to the plastic surgeon, the orthopedic surgeon role in the comprehensive treatment of bone exposures is critical. Often this is the only expert available, and should be able to reconstruct the limb with local muscle flaps, since there may not be another specialist in these situations.

This study aims to evaluate the use of a medial gastrocnemius muscle and / or soleus muscle flap as a surgical treatment of the leg bone exposure.

\section{METHODS}

We conducted a retrospective analysis by active search of medical records of all patients submitted to mobilization of flaps of soleus and gastrocnemius muscles or both to cover the exposure of the leg bones, between January 1976 and July 2009. Data were obtained from the archives of the Plastic Surgery Service of the Clementino Fraga Filho University Hospital, Federal University of Rio de Janeiro (HUCFF / UFRJ), Orthopedics and Traumatology Services of the Miguel Couto County Hospital (RJ) and Agnelo Ciátola Hospital, Barra do Pirai Holy Home of Mercy (RJ).

In addition to epidemiological data, we evaluated the etiology of the injury, the time interval between the initial injury and muscle transposition, the muscle used to cover the lesion, the healing evolution of the skin coverage and the function of the gastrocnemius-soleus unit.

1. Holy House of Mercy, Barra do Pirai, Rio de Janeiro State - RJ, Brazil; 2. Department of Surgery, Faculty of Medicine, Federal University of Rio de Janeiro; 3. Severino Sombra University - USS, Vassouras, RJ; 4. Plastic Surgery Service, Clementino Fraga Filho University Hospital, Federal University of Rio de Janeiro (HUCFF / UFRJ). 
In the short-term postoperative evaluation (0102 months), we analyzed the outcome by observing the skin coverage, considering as: excellent - the healing of the surgical wound without flap suffering; good: Suffering of up to $1 / 3$ of the flap; regular: commitment of up to $1 / 3$ of the flap, with signs of infection; poor: loss greater than $1 / 3$ of the flap and / or infection.

In the analysis of the in long-term results, carried out with a minimum of 12 months after surgery, we evaluated the function of the gastrocnemius-soleus unit and the skin coverage.

\section{Operative Technique}

The surgery started by observing the antiseptic and aseptic techniques, with preparation of the entire lower limb in which the muscle transposition would take place, and also the contralateral thigh when we wanted to use skin graft in the same procedure. After lifting limb for a few minutes, ischemia was made using a crepe bandage or Smarch tape, by inflating the cuff with a mean pressure of $100 \mathrm{mmHg}$ above the blood systolic pressure.

The incision should be directed to the muscle to be used and can be modified according to the preoperative injury, including skin and subcutaneous tissue, and can be made as follows: a) to the medial portion of the gastrocnemius, we began in a curvilinear fashion along its anterior medial edge, till its most distal insertion; b) to the soleus muscle, starting the incision at the level of medial retromalleolar region, along the tendon of the triceps surae, we continue till the transition with the gastrocnemius muscle mass and, from this point, we continue the incision in curvilinear shape along the anterior medial edge of this muscle.

The medial portion of the gastrocnemius is identified and released distally in its muscle-tendon transition, while their communicating vessels are dissected and ligated with 4-0 nylon sutures. The soleus is identified through its terminal muscle mass along the tendon of the triceps surae. From this region, we started its isolation, deinserting it till its transition to the gastrocnemius, ligating their communicating vessels along the intermuscular septum.

After identification of the muscles, we prepare the area to be protected by surgical debridement (in patients with osteomyelitis) and reduction of fractures, which can be achieved by means of internal or external fixation, and also placing a bone graft when there is pseudoarthrosis. We then held a tunneling through the subcutaneous tissue for passing of the muscle to the receiving area, with care not to compress the flap, compromising its vascularization.

A compression bandage is placed over the wound, after the pneumatic cuff is deflated. After the withdrawal of the compressive bandage we proceeded to hemostasis by electrocoagulation. At this stage, the checked the vitality of the distal end of the muscle is to be transposed, already in its final bed.

We then anchored the muscle to subcutaneous tissue or to the skin with 5-0 nylon, and closed the surgical incision with 4-0 nylon. If necessary, we retrieved a skin graft from the lateral region of the opposite thigh, with a electric dermatome or grafting knife, to cover the transposed muscle mass. The dressing is made with furacin or vaseline gauze pads, accompanied by a slightly compressive cushion.

In the immediate postoperative period, the patient is immobilized with a thigh-to-feet plastered splint, the limb being raised with a stick of Braun. The first dressing is done on the 5th day after surgery and the stitches are removed around the 15th day. In the area of the donor skin grafts, one can use vaseline gauze or $1 \%$ silver sulfadiazine cream to accelerate the healing process.

\section{RESULTS}

The group included 53 patients, 42 male and 11 female, age ranging from nine to 84 years, with a mean of 41. The most frequent initial injury was trauma (84.4\%), consisting of tibia and / or fibula fracture. One patient had an erysipelas sequel and another had a great skin tumor (Table 1).

In all cases the initial basic treatment of open fractures consisted of mechanical debridement associated with trans-skeletal traction in 21 cases (39.6\%), bipolar fixation in five $(9.4 \%)$, plaster cast immobilization in two (3.8\%) and external fixation in 10 (18.8\%).

In the cases of closed fractures, we used plates and screws in five cases (9.4\%), performed osteosynthesis with crossed Kirschner wires into two (3.8\%) and employed bipolar fixation in two (3, 8\%).

The time between the initial injury and muscle transposition ranged from one to 46 months, with an average of 6.8. The most frequently used muscle was the soleus, in 40 patients (75.5\%), of whom $31(58.5 \%)$ in injuries of the middle third of the leg, five (9.4\%) in proximal third injuries and four (7.5\%) in lesions of the distal third (Figures 1a, $1 \mathrm{~b}, 1 \mathrm{c})$. We used the medial portion of the gastrocnemius in $12(22.6 \%)$ cases, $10(18.8 \%)$ of which being lesions of the proximal third and two (3.8\%) of the middle third (Figures $2 a, 2 b, 2 c)$. One (1.9\%) patient required the transposition of both muscles (Table 2 ).

The short term evaluation of the skin covering showed that $49(92.5 \%)$ patients had excellent or good outcome, three $(5.6 \%)$, regular and one $(1.9 \%)$ unsatisfactory (Table 3). A long-term evaluation was performed in 26 patients (49\%). Of these, 25 (96.2\%) had no alterations. In the patient submitted to transposition of both muscles, there was decreased muscle strength, although his march had remained normal. 
Table 1 - Diagnosis before muscle transposition.

\begin{tabular}{lrc}
\hline Diagnosis & Number & $\%$ \\
\hline Fracture of tibia and/or fibula & 45 & $84,8 \%$ \\
Pseudarthrosis & 5 & $9,5 \%$ \\
Varicose ulcer & 1 & $1,9 \%$ \\
Skin cancer (squamous cell carcinoma) & 1 & $1,9 \%$ \\
Erysipelas with bone exposure & 1 & $1,9 \%$ \\
Total & 53 & $100 \%$ \\
\hline
\end{tabular}

\%: percentage of total cases.

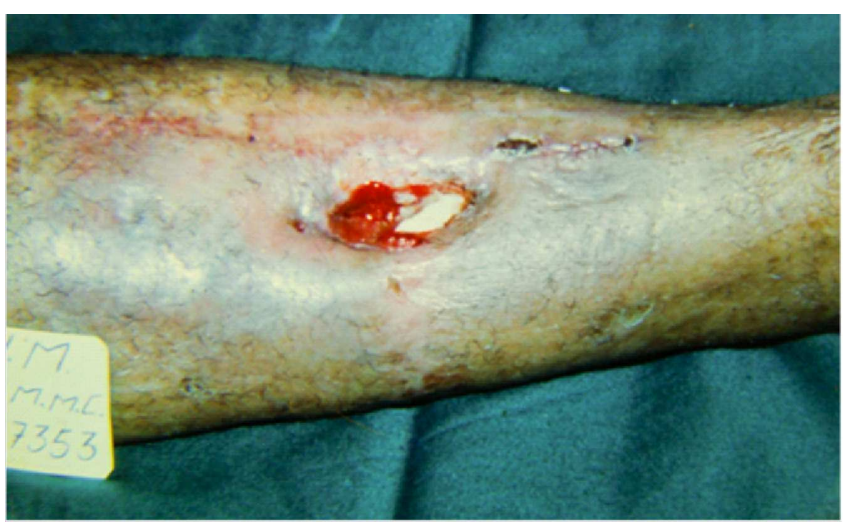

Figure $1 \boldsymbol{A}$ - Bloody area in the lower third of the leg.

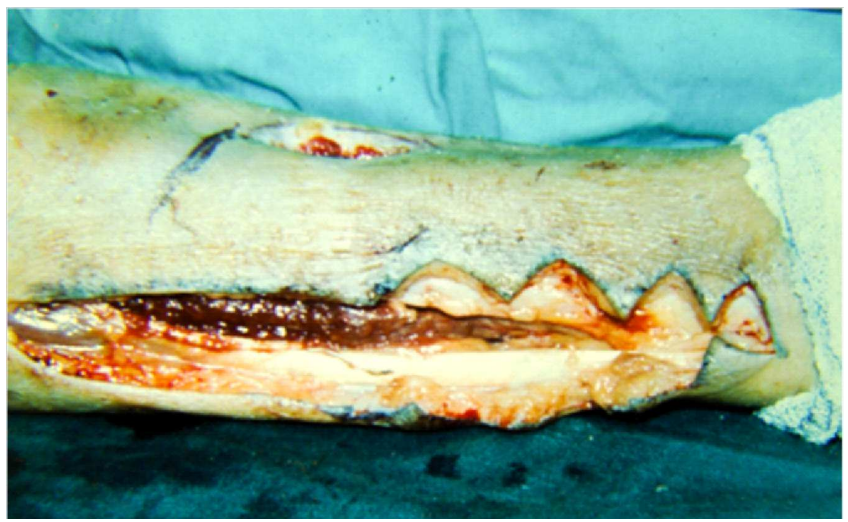

Figure 2 - $\quad$ Access to isolation of the soleus muscle.

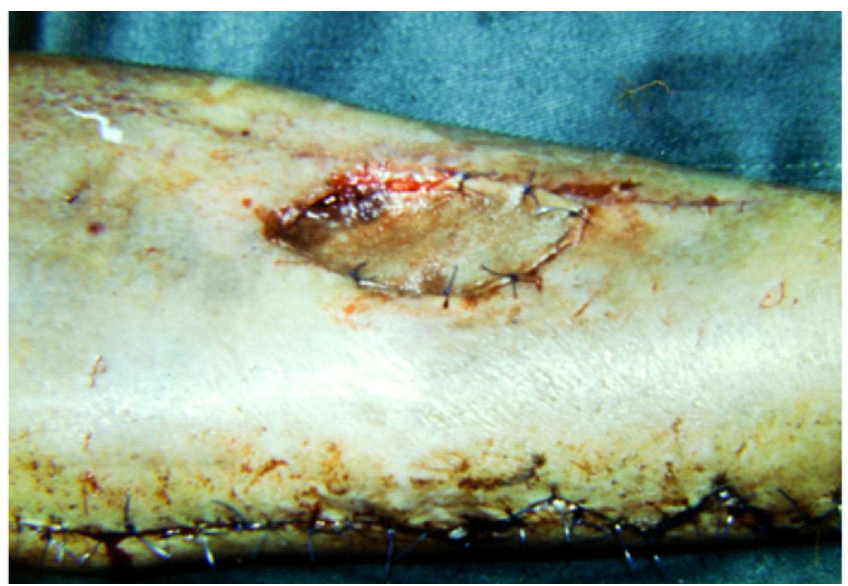

Figure 3 - Soleus muscle transposed and covered by skin grafting.

\section{DISCUSSION}

The treatment of skin loss resulting from traumatic, infectious and vascular (ulcerations) processes is a challenge for surgeons and often requires the assistance of specialized techniques of plastic surgery and microsurgery.

The vascular conditions of the lower limb, both arterial as venous, should be evaluated carefully, both pre and postoperatively. Diseases affecting the microvasculature or vascular lesions are common and may prevent apparently well-planned flaps. Moreover, postoperative immobilization, essential in most cases, is a predisposing factor for thromboembolic complications.

The use of skin grafts in these lesions in isolation is hampered by the scarce vascular bed and the poor granulation of wounds, often associated with prolonged exposure of deep structures, such as bone, tendon and blood vessel, and may be exacerbated by infections, as osteomyelitis. When the realization of these grafts was needed, it was necessary to wait for the development of granulation tissue to cover the exposed bone surface, serving as a recipient bed. We know that prolonged bone exposure leads to bone necrosis and consequently favors the installation of infectious processes that lead to tissue necrosis 1. In our study, the time interval between the initial injury and muscle transposition varied from one to 46 months. We noted that from 1980 on, the time was reduced, as we indicated the muscle transposition earlier, different from the past, when patients were submitted to different treatments (skin grafts, bone curettage, cross-leg type flaps) and evolved unsatisfactorily.

The fasciocutaneous or fascial flaps of distal pedicle can be a good alternative to the distal regions, although this requires a good local circulation ${ }^{2-4}$. The microsurgical free flap has become a frequent indication. However, microsurgical techniques require specialized training and in most hospitals there are no specialists available to carry them out. In addition, such patients usually require additional operations to ${ }^{5-7}$.

The gastrocnemius and soleus muscles, being vascularized predominantly in their proximal regions, allow the rotation about the axis of the pedicle (good arc of rotation), without compromising vitality. They thus offer a good option for bone and soft tissue coverage of the 


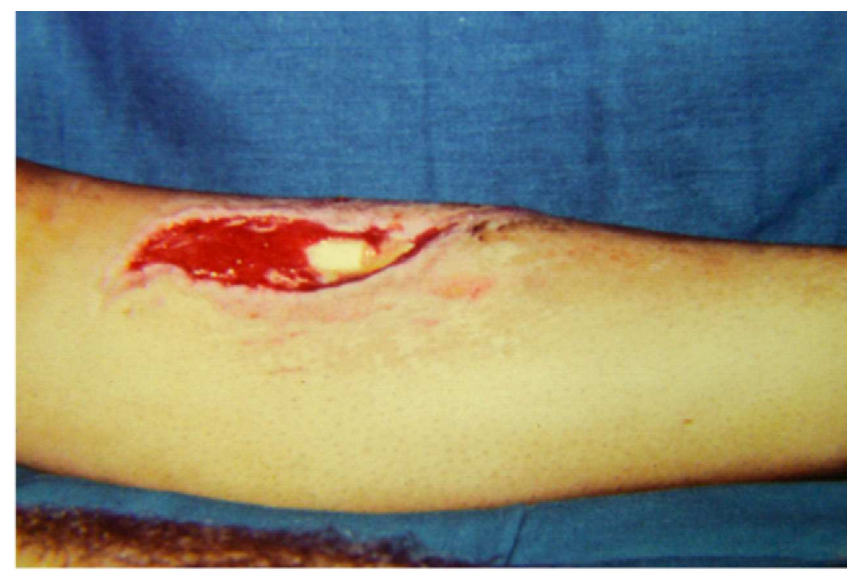

Figure 4 - Wound in the middle third of the leg.

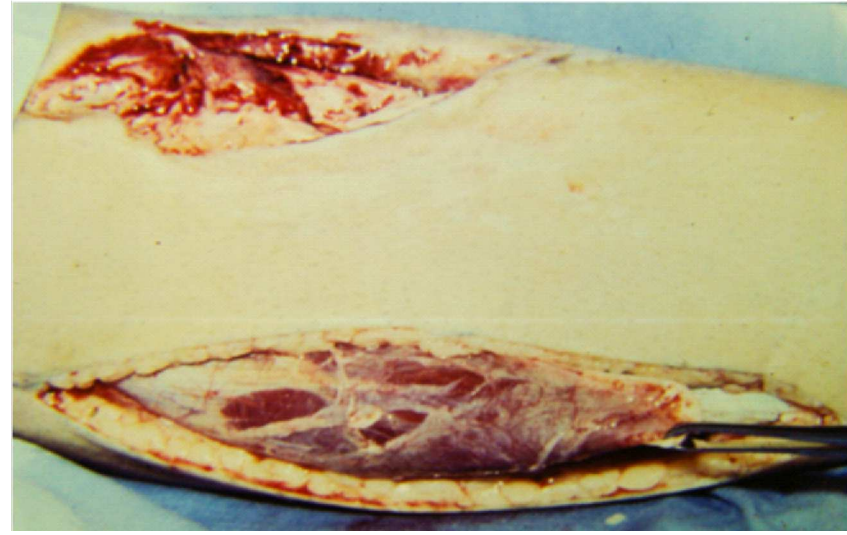

Figure 5 - Medial belly of gastrocnemius muscle isolated and ready for rotation.

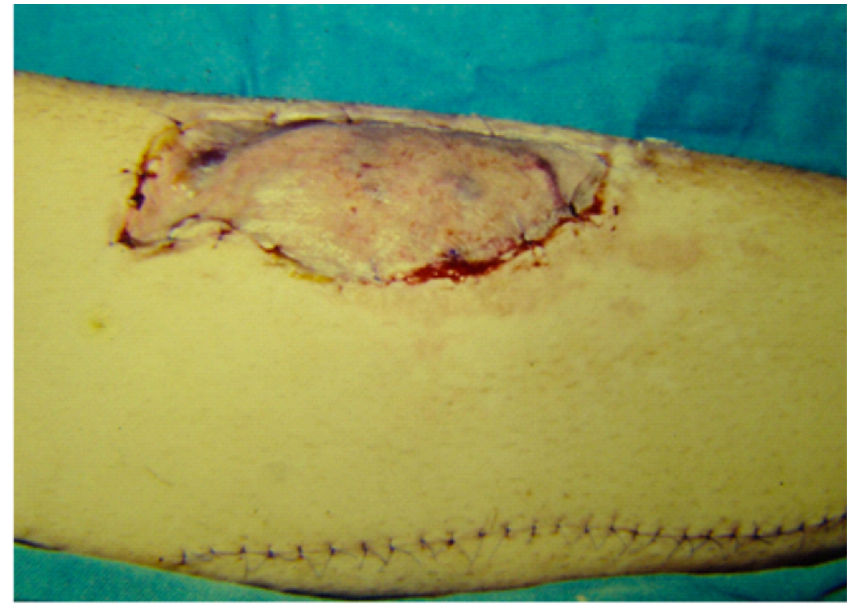

Figure 6 - Gastrocnemius muscle covered by skin grafting. proximal and middle thirds of the leg, being the most used, usually individually ${ }^{8-16}$. In some situations, one may employ the soleus associated with one of the belies of the gastrocnemius ${ }^{17}$. It is not the most common, but keeping at least one functioning belly of the gastrocnemius, we can preserve part of the segment function. We use the medial portion of the gastrocnemius for lesions of the proximal third of the tibia and the soleus for lesions of the middle and distal thirds.

Muscle flaps have limited use in the distal end of the leg and foot and are unsafe when compared with those for the proximal and middle thirds of the leg. We used the soleus flap with good resolution in four patients who had lesions in the upper distal third. Despite the lack of vascularization as safe as with the soleus muscle flap with a proximal pedicle, the flap of this muscle with reverse pedicle can solve various situations ${ }^{16}$. For lower lesions, we may use the calf fascial-subcutaneous flap, since its retrograde vascularization is preserved ${ }^{3}$. The cross-leg flap may also be employed, but due to the inconveniences caused to the patient by prolonged immobilization and the uncomfortable rest position, we prefer not to indicate it.

We know that muscle transposition improves the blood supply to the receiving region, contributing significantly to the treatment of infection and promoting the healing process of tissues, including bone. This method allows the primary treatment of skin defects and, in some cases, also of the bone damage. Therefore, it is indicated as an aid in the treatment of varicose ulcers, fractures, osteomyelitis and pseudoarthrosis with exposed bone or scar adherent to the bone ${ }^{1,18-30}$.

Knowledge of anatomy and surgical technique make the transposition of these muscles a feasible procedure for surgeon, who, with practice, starts to spend less time in the procedure than with other techniques, such as microsurgical flaps.

We did not observe any independent functional deficit as for the muscle transposition of the medial portion of the gastrocnemius and soleus in 25 of the 26 patients who returned for revision 12 months after the procedure. The absence of many patients for this review can probably be explained by their low economic status and distant origin. We carried out the concomitant implementation of both muscles in only one patient, who had extensive bone exposure that could not be protected with the transposition of only one muscle. The lateral gastrocnemius belly was

Table 2 - Flap used and level of injury.

\begin{tabular}{lccccc}
\hline Level of injury & Soleus & GM & Soleus + GM & Total & $\%$ \\
\hline Proximal $1 / 3$ & 5 & 10 & 1 & 16 & $30.2 \%$ \\
Middle $1 / 3$ & 31 & 2 & 0 & 33 & $62.3 \%$ \\
Distal $1 / 3$ & 4 & 0 & 0 & 4 & $7.5 \%$ \\
Total & & 40 & 12 & 1 & $53100 \%$ \\
\hline
\end{tabular}

GM: medial portion of the gastrocnemius muscle; \%: percentage of total cases. 
preserved. The walking ability was maintained, but there was partial loss of limb strength.

Once respected the circulatory anatomy of the transposed muscles, the patient may be submitted, if necessary, to a new surgical intervention after wound healing, as in cases requiring treatment of bone injuries (bone loss, pseudoarthrosis, osteomyelitis). As regards the aesthetic sequel, we consider to be perfectly acceptable with respect to other procedures within the reconstructive surgery arsenal.

We deem the rotation of local muscle flaps a feasible procedure to the assistant surgeon, with simple technique. It provides coverage of exposed structures, favoring the local circulation and improvement of the initial injury. Adequate aesthetic and functional results are often obtained.

In conclusion, the treatment of bone exposure with local muscle flaps (gastrocnemius and/or soleus) made possible to obtain satisfactory results in the coverage of exposed structures, favoring the local blood supply and the improvement of the initial injury. It offers the advantage of providing treatment in only one surgical procedure, faster recovery and reduced hospital stay.

\section{R E S U M O}

Objetivo: avaliar o uso de retalhos de porção medial do músculo gastrocnêmio elou de músculo sóleo como tratamento cirúrgico de exposição óssea da perna. Métodos: foram analisados, retrospectivamente, os prontuários de pacientes submetidos à transposição dos músculos gastrocnêmio medial elou sóleo para tratar exposição óssea na perna, no período de janeiro de 1976 a julho de 2009. Foram avaliados, além dos dados epidemiológicos, a etiologia da lesão, o intervalo de tempo decorrido entre a lesão inicial e a transposição muscular, o músculo utilizado para cobrir a lesão, a evolução da cicatrização da cobertura cutânea e a função da unidade gastrocnêmio-sóleo. Resultados: foram operados 53 pacientes, variando a faixa etária entre 09 e 84 anos (média de idade de 41 anos), sendo 42 do sexo masculino e 11 do sexo feminino. A lesão inicial principal foi de origem traumática (84,8\%), consistindo de fratura de tíbia elou fíbula. O músculo utilizado com maior frequência foi o sóleo em 40 casos (75,5\%). Classificou-se 49 pacientes (92,5\%) como resultado excelente ou bom, 03 (5,6\%) como regular e 01 (1,9\%) como insatisfatório. Conclusão: o tratamento da exposição óssea com retalhos musculares locais (gastrocnêmio e ou sóleo) possibilita a obtenção de resultados satisfatórios na cobertura das estruturas expostas, favorecendo a vascularização local e melhora da lesão inicial. Apresenta como vantagens a realização do tratamento em um só tempo cirúrgico, uma recuperação mais precoce e diminuição do tempo de internação.

Descritores: Extremidade inferior; Músculo esquelético; Retalho miocutâneo; Pernas - cirurgia.

\section{REFERENCES}

1. Paccola CAJ. Fraturas expostas. RevBras Ortop. 2001;36(8):283291.

2. Franco T, Couto P, Gonçalves LFF, Franco D, Silva CC. Tratamento das exposições ósseas e tendinosas no terço distal da perna e no pé utilizando retalho fasciossubcutâneo reverso de panturrilha. Ver Bras Ortop. 1996;31(3):247-52.

3. Vendramin FS, Silva, Claudio-da-Silva CS. Retalho sural estendido de pedículo distal. Rer Col Bras Cir. 2004;31(4):248-52.

4. Vendramin FS. Retalho sural de fluxo reverso: 10 anos de experiência clínica e modificações. Ver Bras Cir Plást. 2012;27(2):30915.

5. Zumiotti AV, Teng HW, Ferreira MC. Treatment of post-traumatic tibial osteomyelitis using microsurgical flaps. J Reconstr Microsurg. 2003;19(3):163-71

6. Rezende MR, Rabelo NTA, Benabou JE, Wei TH, Mattar Junior R, Zumiotti AV, et al. Cobertura do terço distal da perna com retaIhos de perfurantes pediculados. Acta Ortop Bras. 2008;16(4):2239.

7. Garcia AMC. Retalho sural reverso para reconstrução distal da perna, tornozelo, calcanhar e do pé. Rev Bras Cir Plást. 2009;24(1):96-103.

8. Bacelar TH. Utilização do músculo sóleo para perdas musculocutâneas de terço médio da perna. Rev Bras Cir Plást. 2011:26(2):211-20.
9. Jentzsch $T$, Erschbamer M, Seeli F, Fuchs B. Extensor function after medial gastrocnemius flap reconstruction of the proximal tibia. ClinOrthopRelat Res. 2013;471(7):2333-9.

10. Torres LR, Teixeira WGJ, Setani EO, Wei TH, Zumiotti AV. Retalho cutâneo das artérias perfurantes do músculo gastrocnêmio medial: estudo anatômico. Acta Ortop Bras. 2007;15(1):40-2

11. Rebouças DM, Silva LL, Cunha FR, Souza Fl, Moraes FB, Rebouças Junior FA, Kuwae MY, Rocha VL. Estudo anatômico das artérias perfurantes do músculo gastrocnêmio medial. RevBras Ortop. 2008;43(4):133-7.

12. Buchner M, Zeifang F, Bernd L. Medial gastrocnemius muscle flap in limb-sparing surgery of malignant bone tumors of the proximal tibia: mid-term results in 25 patients. Ann PlastSurg. 2003:51(3):266-72.

13. Ries MD, Bozic KJ. Medial gastrocnemius flap coverage for treatment of skin necrosis after total knee arthroplasty. ClinOrthopRelat Res. 2006;446:186-92

14. Moraes FB, Paranahyba RM, Oliveira E, Kuwae MY, Rocha VL. Estudo anatômico do músculo gastrocnêmio medial visando transferência muscular livre funcional. RevBras Ortop. 2007;42(8):2615.

15. Li X, Yang ZP, Li JM. Soft tissue reconstruction with sagital split anterior tibial muscle transfer and medial gastrocnemius transposition in limb-salvage surgery of bone tumors in a proximal tibia. Ann Plast Surg. 2008;61(2):204-8. 
16. Souza Filho MVP, Teixeira JCEO, Castro OC. Retalho hemissolear reverso na reconstrução de defeito do terço distal da perna. RevBrasCirPlást. 2011;26(4):710-3.

17. Sundell B, Asko-Seljavaara S. Transposition of muscle flaps for covering exposed bone in the leg. Ann ChirGynaecol. 1979;68(1):15.

18. Nejedly A, Dzupa V, Záhorka J, Tvrdek M. [Muscle flap transfer of the treatment of infected tibial and malleolar fractures and chronic osteomyelitis of the tibia]. ActaChirOrthopTraumatolCech. 2007;74(3):162-70.Czech.

19. Mathes SJ, McCraw JB, Vasconez LO. Muscle transposition flaps for coverage of lower extremity defects: anatomic considerations. SurgClin North Am. 1974;54(6):1337-54.

20. Graziano TA, Giampapa V. Muscle transposition in the management of chronic osteomyelitis and ulceration of the heel. J Foot Surg. 1989;28(1):68-71.

21. Hughes LA, Mahoney JL. Anatomic basis of local muscle flaps in the distal third of the leg. PlastReconstr Surg. 1993;92(6):114454 .

22. Cortez M, Borges LG, Lima SC. Um novo retalho muscular para cobertura do terço inferior da perna e do pé. RevBras Ortop. 1993;28(9):687-93.

23. Pawlas R. [Use of muscular and cutaneous fascial flaps in treatment of open tibial fracture with soft tissue defects]. ChirNarzadowRuchuOrtop Pol. 1995;60(6):503-8. Polish.

24. Arnold PG, Yugueros P, Hanssen AD. Muscle flaps in osteomyelitis of the lower extremity: a 20-year account. PlastReconstr Surg. 1999;104(1):107-10.
25. Severo AL, Scorsatto C, Valente EB, Lech OLC. Retalhos para reconstrução de perdas musculocutâneas em membros inferiores: análise de 18 casos. RevBras Ortop. 2004;39(10):578-89.

26. Zumiotti AV. A importância do revestimento cutâneo no tratamento das osteomielites pós-traumáticas. RevBras Ortop. 2004;39(8):403-5.

27. Fansa $\mathrm{H}$, Frerichs $\mathrm{O}$, Schneider $\mathrm{W}$. [Distally pedicled peroneus brevis muscle flap for defect coverage on the lower leg]. Unfallchirurg. 2006:109(6):453-6. German.

28. El-Khatib HA. The split peroneus muscle flap: a new flap for lower leg defects. J PlastReconstrAesthet Surg. 2007;60(8):898-903.

29. Rios-Luna A, Fahandezh-Saddi H, Villanueva-Martínez M, López AG. Pearls and tips in coverage of the tibia after a high energy trauma. Indian J Orthop. 2008;42(4):387-94.

30. Ahmad I, Akhtar S, Rashidi E, Khurram MF. Hemisoleus muscle flap in the reconstruction of exposed bonés in the lower limb.J Wound Care. 2013;22(11): 635, 638-40, 642.

Received 02/01/2014

Accepted for publication 03/03/2014

Conflict of interest: none.

Source of funding: none.

\section{Mailing address:}

Dr. Francisco d'Avila.

E-mail: dr.fdavila@yahoo.com.br 